\title{
Correction: Loss of HSulf-1 promotes altered lipid metabolism in ovarian cancer
}

\author{
Debarshi Roy ${ }^{1 \dagger}$, Susmita Mondal ${ }^{1 \dagger}$, Chen Wang ${ }^{2 \dagger}$, Xiaoping He${ }^{1}$, Ashwani Khurana', Shailendra Giri ${ }^{3}$, \\ Robert Hoffmann ${ }^{1}$, Deok-Beom Jung ${ }^{4}$, Sung H Kim ${ }^{4}$, Eduardo N Chini ${ }^{5}$, Juliana Camacho Periera ${ }^{5}$, \\ Clifford D Folmes ${ }^{6}$, Andrea Mariani ${ }^{7}$, Sean C Dowdy ${ }^{7}$, Jamie N Bakkum-Gamez ${ }^{7}$, Shaun M Riska ${ }^{2}$, Ann L Oberg ${ }^{2}$, \\ Edward D Karoly ${ }^{8}$, Lauren N Bell ${ }^{8}$, Jeremy Chien ${ }^{9}$ and Viji Shridhar ${ }^{1 *}$
}

\section{Correction}

After publication of this manuscript [1], it has been brought to our attention that we have on several occasions referred to the long-chain acyl-CoA synthetase as ASCL1. In all such cases, the correct abbreviation of ACSL1 should have been used.

\begin{abstract}
Author details
'Department of Experimental Pathology, Mayo Clinic College of Medicine, Rochester, MN 55905, USA. ${ }^{2}$ Division of Biomedical Statistics and Informatics, Mayo Clinic, Rochester, MN 55905, USA. ${ }^{3}$ Henry Ford Health System, Detroit, MI 48202, USA. ${ }^{4}$ Cancer Preventive Material Development Research Center (CPMRC), College of Oriental Medicine, Kyunghee University, Seoul 130-701, Republic of Korea. ${ }^{5}$ Department of Anesthesiology, Mayo Clinic College of Medicine, Rochester, MN 55905, USA. 'Department of Cardiovascular Disease, Mayo Clinic College of Medicine, Rochester, MN 55905, USA. ${ }^{7}$ Department of Obstetrics and Gynecology, Mayo Clinic College of Medicine, Rochester, MN 55905, USA. ${ }^{8}$ Metabolon, Inc, Durham, NC 27713, USA. ${ }^{9}$ Department of Cancer Biology, University of Kansas Medical Center, Kansas City, KN 66160, USA.
\end{abstract}

Received: 17 October 2014 Accepted: 17 October 2014

Published: 4 November 2014

\section{Reference}

1. Roy D, Mondal S, Wang C, He X, Khurana A, Giri S, Hoffmann R, Jung D-B, Kim SH, Chini EN, Periera JC, Folmes CD, Mariani A, Dowdy SC, BakkumGamez JN, Riska SM, Oberg AL, Karoly AL, Bell LN, Chien J, Shridhar V: Loss of HSulf-1 promotes altered lipid metabolism in ovarian cancer. Cancer Metabol 2014, 2:13.

\section{Submit your next manuscript to BioMed Central and take full advantage of:}

- Convenient online submission

- Thorough peer review

- No space constraints or color figure charges

- Immediate publication on acceptance

- Inclusion in PubMed, CAS, Scopus and Google Scholar

- Research which is freely available for redistribution

\footnotetext{
* Correspondence: shridhar.vijayalakshmi@mayo.edu

${ }^{\dagger}$ Equal contributors

'Department of Experimental Pathology, Mayo Clinic College of Medicine, Rochester, MN 55905, USA
}

Submit your manuscript at

\section{Biomed Central}

(C) 2014 Roy et al.; licensee BioMed Central Ltd. This is an Open Access article distributed under the terms of the Creative Commons Attribution License (http://creativecommons.org/licenses/by/4.0), which permits unrestricted use, distribution, and reproduction in any medium, provided the original work is properly credited. The Creative Commons Public Domain Dedication waiver (http://creativecommons.org/publicdomain/zero/1.0/) applies to the data made available in this article, unless otherwise stated. 